\title{
Model selection for measuring security price performance
}

\author{
M.J. Page \\ Graduate School of Business, University of Cape Town, Private Bag, Rondebosch, 7700 Republic of South Africa
}

Received 12 September 1988; accepted 19 October 1988

\begin{abstract}
In this article a bootstrapping routine is used to compare the efficiency of different benchmarks that can be used for measuring security price performance on the Johannesburg Stock Exchange. Four approaches are compared; three benchmarks based on the theory of the Capital Asset Pricing Model, and one, a two-factor benchmark, based on the theory of the Arbitrage Pricing Model. The findings show that, for the JSE, the twofactor approach is superior. This is consistent with prior research into the South African securities market where evidence of two clear factors influencing security returns have been found. The recommendation is that the twofactor benchmark be used for measuring security price performance on the JSE, especially for small samples where only limited benefits can be expected through the central limit theorem.
\end{abstract}

Die effektiwiteit van verskillende metodes om effekteprysprestasie op die Johannesburgse Effektebeurs te meet, word in hierdie artikel vergelyk deur gebruik te maak van die 'bootstrapping'-roetine. Vier benaderings word vergelyk; drie prosedures gebaseer op die markpryswaarderingsmodel, en 'n twee-faktorprosedure gebaseer op die Arbitrage-prysbepalingsmodel. Die analise toon aan dat die twee-faktorbenadering die effektiefste is vir die meting van effekteprysprestasie op die Johannesburgse Effektebeurs. Hierdie bevinding is in lyn met vorige navorsing op die Suid-Afrikaanse effektemark waar bevind is dat twee duidelike faktore effekte-opbrengs beïnvloed. Daar word aanbeveel dat die twee-faktorprosedure gebruik word om effekteprysprestasie op die Johannesburgse Effektebeurs te meet; veral in die geval van klein steekproewe waar beperkte voordele verwag kan word in terme van die sentrale-limietstelling.

\section{Introduction}

Abnormal security returns can only be determined relative to a particular benchmark. The benchmark is required to establish what constitutes normal security returns, and the abnormal returns are the difference between the actual observed returns and those predicted by the model.

In order to be truely acceptable the benchmark model must be based on sound financial theory. Most benchmarks have therefore been constructed so as to be consistent with the Capital Asset Pricing Model. Three such models have been evaluated by Brown and Warner. They are the mean adjusted returns model, the market adjusted returns model, and the market and risk adjusted returns model (Brown \& Warner, 1980). With the development of the Arbitrage Pricing Theory in 1976 (Ross, 1976) a theoretical framework was provided for the establishment of multi-factor benchmark models. Benchmarks of this type were initially examined by Brown and Weinstein in 1983 (Brown \& Weinstein, 1985).

Considerable evidence exists to suggest that there are two clearly distinguishable factors influencing security performance on the Johannesburg Stock Exchange. This is due to the substantial impact of the mining industry on the South African economy. Gilbertson \& Goldberg (1981) found evidence of both mining and industrial factors on the Johannesburg Stock Exchange and their findings were further substantiated by initial research into the Arbitrage Pricing Theory (Page, 1986). In South Africa therefore, it is likely that a multi-factor approach will show a more significant improvement over the CAPM based approaches than Brown and Weinstein found to be the case for the New York Stock Exchange.

In this paper a bootstrapping routine has been used to compare the three CAPM based models mentioned above and a two-factor APT based model. A two-factor model was selected because, as stated above, there are at least two factors evident in the South African stock market.

\section{Review of the benchmark models}

The mean adjusted returns model

The mean adjusted returns model assumes that the expected return on a security is constant. The constant may however differ across securities. The model is consistent with the CAPM under the assumption that the expected excess return on the market is a constant.

\section{The market adjusted returns model}

The market adjusted returns model assumes that the expected returns on all securities are equal. The expected returns are not necessarily constant and may vary through time. The model is therefore also consistent with the CAPM if all securities have systematic risk of unity.

\section{The market and risk adjusted returns model}

The market and risk adjusted returns model assumes that the expected return on a security is generated by the CAPM. The model allows for securities with systematic risk not equal to unity.

\section{The multi-factor returns model}

The multi-factor model assumes that the expected return on a security is determined by its sensitivity to several market-wide factors. The model is consistent with the APT. 


\section{Model comparison}

In this study the models are compared by using an expost forecasting procedure (Pindyck \& Rubinfeld, 1981). This is a two-step procedure that involves first estimating the parameters of each of the models using a subset of the data and then computing the abnormal returns for each model using the rest of the data and comparing the results across the models.

Several statistics are available for comparing the models and these are outlined and briefly discussed below.

\section{Root-mean-square simulation error}

This measure is the one that is most often used to determine how closely the ex-post forecast tracks the actual outcome. The rms simulation error is defined as:

rms error $=\sqrt{\sum_{t=1}^{T}\left(R_{t}^{f}-R_{t}^{a}\right)^{2} / T}$

where; $R_{t}^{f}=$ ex-post forecasted value in period $t ; R^{a}{ }_{t}=$ actual outcome in period $t ; T=$ number of periods.

\section{Mean simulation error}

The mean simulation error gives an indication of degree of bias in the forecast. This error should be close to zero. The mean simulation error is defined as:

mean error $=\sum_{t=1}^{T}\left(R_{t}^{f}-R^{a}{ }_{t}\right) / T$

\section{Mean-absolute simulation error}

As with the rms simulation error the mean-absolute simulation error is a measure of how closely the ex-post forecast tracks the actual observation. The difference between the two being that the mean-absolute simulation error penalizes large individual errors less than the rms simulation error. The mean absolute error is defined as:

mean-absolute error $=\sum_{t=1}^{T} \mid R_{t},-R^{a}, V T$

Theil's inequality coefficient

This coefficient can be viewed as a standardized form of the rms simulation error. The coefficient will always fall between zero and one. A coefficient of zero would result if the forecast was perfect while a coefficient of one would imply the forecast could not be worse. Theil's inequality coefficient $U$ is given by:

$$
U=\frac{\sqrt{\sum_{t=1}\left(R_{t}-R^{a} t\right)^{2} / T}}{\sqrt{\sum_{t=1}\left(R_{t}\right)^{2} / T}+\sqrt{\sum_{t=1}\left(R_{t}^{a}\right)^{2} / T}}
$$

The coefficient can be broken down into three proportions of inequality. A bias proportion, $U^{m}$, a variance proportion, $U^{s}$, and a covariance proportion, $U^{c}$.

$$
\begin{aligned}
& U^{m}=\frac{\left(\bar{R}^{f}-\bar{R}^{a}\right)^{2}}{\sum_{t=1}^{T}\left(R_{t}^{f}-R^{a}\right)^{2} / T} \\
& U^{s}=\frac{\left(\sigma_{f}-\sigma_{a}\right)^{2}}{\sum_{t=1}^{T}\left(R_{t}^{f}-R_{t}^{a}\right)^{2} / T} \\
& U^{c}=\frac{2(1-\varphi) \sigma_{f} \sigma_{a}}{\sum_{t=1}^{T}\left(R_{t}^{f}-R_{t}^{a}\right)^{2} / T}
\end{aligned}
$$

where $\bar{R}^{f}, \bar{R}^{a}=$ means of the respective series; $\sigma_{f}, \sigma_{a}=$ standard deviations of the two series; $\varphi=$ correlation between the series.

The bias proportion gives an indication of the systematic error and should be as close to zero as possible. The variance proportion measures the extent to which the variability of the actual outcomes is replicated by the forecast. This proportion should also be as close to zero as possible. The covariance proportion measures the unsystematic error and, given that forecasts cannot be expected to be perfectly correlated with the actual outcomes, is expected to be close to unity.

\section{Research methodology}

Thirty well-traded securities were randomly selected from the Johannesburg Stock Exchange and their weekly excess returns calculated for the four years beginning January 1981 and ending December 1984. The criterion for selection was that each security should trade in at least fifty-one weeks in each year. The 91 day Treasury Bill rate was used for the risk free rate.

The annualized percentage excess returns for the $i$ th security were calculated using:

$R_{i f}=\ln \left(P_{i /} / P_{i(t-1)}\right) \times 5200$

$R^{e_{i t}}=R_{i t}-R_{f}$

where $R_{i t}=$ annualized return in week $t ; P_{i t}=$ security price at the end of week $t ; \ln =$ natural logorithm; $R^{e}{ }_{i t}=$ excess return in week $t$; and $R_{f}=$ risk free rate.

The excess returns on the JSE overall index were calculated in the same fashion for use as a surogate for the market return.

The final database used for the bootstrapping procedure was constructed by extracting every second period excess return for each security and creating a returns matrix of 100 observations by the 30 securities. An equivalent vector of length 100 containing the excess market returns was also created.

The bootstrapping procedure involved carrying out 250 repetitions of the following steps:

1. Using random sampling with replacement extract 100 period returns and construct a new returns matrix and 
market returns vector. These returns are used for the parameter estimation in steps $2-4$.

2. Compute the mean and standard deviation for each security and the market.

3. Regress each security's excess returns against the excess returns on the market to obtain estimates of the regression coefficients $\alpha_{i}$ and $\beta_{i}$.

4. Construct a correlation matrix of the securities and use maximum likelihood factor analysis to compute the factor loading matrix and the factor score coefficient matrix. Convert the factor loading matrix and the factor score coefficient matrix to allow for the non-standardized form of the returns matrix.

5. For the periods not selected in step 1 for the parameter estimation compute the expected returns for each security using each of the five models shown in Table 1.

6. Compute the abnormal return series for each security for the forecast period as well as the statistics outlined in the section on 'Model comparison'.

\section{Results}

Carrying out the bootstrapping procedure outlined above resulted in 7500 of each of the statistics being computed for each model.

Table 2 shows the number of times each model was found to be the best for each statistic.

In Table 3 the results of pairwise comparisons of the models are presented. The table gives the percentage of times the column model was found to be superior to the row model. The paired percentages do not necessarily add to $100 \%$ because of instances of model equivalence.

Table 1 Expected returns models

\begin{tabular}{|c|c|}
\hline Model 1 & $\begin{array}{l}\text { Mean adjusted returns } \\
R^{e}{ }_{i t}=\tilde{R}_{i}\end{array}$ \\
\hline Model 2 & $\begin{array}{l}\text { Market adjusted returns } \\
R_{i t}{ }_{i t}=R_{m t}\end{array}$ \\
\hline Model 3 & 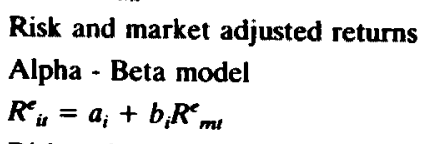 \\
\hline Model 4 & $\begin{array}{l}\text { Risk and market adjusted returns } \\
\text { Beta model } \\
R_{i t}^{e}=b_{i} R_{m t}^{e}\end{array}$ \\
\hline Model 5 & $\begin{array}{l}\text { Multi-factor returns } \\
R_{i t}^{e}=a_{0 i}+a_{1 i} F_{1 i}+a_{2 i} F_{2 i} \\
\text { where } F_{i n}=\Sigma b_{j i} R_{i t} \text { for } j=1,2\end{array}$ \\
\hline
\end{tabular}

Table 2 Best model frequencies

\begin{tabular}{lrrrrr}
\hline Model number & 1 & 2 & 3 & 4 & 5 \\
\hline rms error & 189 & 580 & 406 & 632 & 5693 \\
mean error & 1223 & 1698 & 1031 & 1871 & 1677 \\
mean-absolute error & 354 & 551 & 463 & 981 & 5160 \\
Theil's coefficient & 2 & 1600 & 385 & 303 & 5283 \\
\hline
\end{tabular}

Table 3 Pairwise model comparison showing the column model percentage superiority

\begin{tabular}{|c|c|c|c|c|c|c|}
\hline & Model & 1 & 2 & 3 & 4 & 5 \\
\hline \multirow[t]{5}{*}{ Root-mean-square error } & 1 & - & 86,5 & 92,9 & 93,5 & 95,7 \\
\hline & 2 & 13,5 & - & 71,6 & 78,0 & 86,0 \\
\hline & 3 & 7,1 & 28,4 & - & 61,2 & 85,1 \\
\hline & 4 & 6,5 & 22,0 & 38,7 & - & 81,7 \\
\hline & 5 & 4,3 & 14,0 & 14,9 & 18,3 & - \\
\hline \multirow[t]{5}{*}{ Mean error } & 1 & - & 32,4 & 61,4 & 67,9 & 64,6 \\
\hline & 2 & 67,6 & - & 41,6 & 53,9 & 45,9 \\
\hline & 3 & 38,6 & 58,4 & - & 61,2 & 56,7 \\
\hline & 4 & 32,1 & 46,1 & 38,8 & - & 43,5 \\
\hline & 5 & 35,4 & 54,1 & 43,3 & 56,5 & - \\
\hline \multirow[t]{5}{*}{ Mean-absolute error } & 1 & - & 17,6 & 88,6 & 90,2 & 92,3 \\
\hline & 2 & 82,4 & - & 73,6 & 81,0 & 83,7 \\
\hline & 3 & 11,4 & 26,4 & - & 60,4 & 80,3 \\
\hline & 4 & 9,8 & 19,0 & 37,7 & - & 75,1 \\
\hline & 5 & 7,7 & 16,3 & 19,7 & 24,9 & - \\
\hline \multirow[t]{5}{*}{ Theil's Coefficient } & 1 & - & 99,9 & 99,7 & 96,7 & 100,0 \\
\hline & 2 & 0,1 & - & 49,8 & 49,0 & 77,6 \\
\hline & 3 & 0,3 & 49,9 & - & 43,1 & 88,9 \\
\hline & 4 & 3,3 & 50,6 & 46,3 & & 88,7 \\
\hline & 5 & 0,0 & 22,1 & 10,8 & 10,9 & - \\
\hline
\end{tabular}

Table 4 Theil's proportions of inequality

\begin{tabular}{lccccc}
\hline Model & 1 & 2 & 3 & 4 & 5 \\
\hline$U^{m}:$ bias & 0,045 & 0,028 & 0,046 & 0,029 & 0,045 \\
$U^{s}:$ variance & $0,955^{\mathrm{a}}$ & $\mathbf{0 , 3 3 0}$ & 0,298 & 0,303 & 0,231 \\
$U^{c}:$ covariance & 0,000 & 0,641 & 0,657 & 0,669 & 0,724 \\
\hline
\end{tabular}

a the high model 1 variance proportion results because, by construction, the covariance proportion must be zero

The average Theil's proportions of inequality are given in Table 4. These, as discussed under 'Theil's inequality coefficient', are useful in explaining the sources of the simulation error.

\section{Conclusions}

An analysis of Table 2 shows that the two factor model is the best on the basis of three of the four statistics. It is only with regard to the mean error that it does not rank as the best model.

A comparison of the two forms of the market and risk adjusted returns model shows that the second form of assuming alpha equal to zero results in a better forecast. This perhaps reflects the fact that the true alphas are zero. In most instances estimates of alpha are found to be not significantly different from zero (Page, 1986).

The pairwise comparisons presented in Table 3 also clearly indicate that the factor approach is superior in all but the mean error test. The fact that the factor model is 
better than the other models for a higher percentage of times using the root-mean-square error than for the mean-absolute errors indicates that it has proportionately smaller extreme abnormal returns than the other models.

Generally the mean adjusted returns and market adjusted returns models performed poorly compared to the other approaches. In comparing the two, however, the mean adjusted returns model outperformed the market adjusted returns model on the mean error criterion. This occurred because most securities have betas different from one and, for the period under examination, the mean excess returns were different from zero. This condition induces a bias in the market adjusted returns model. On the basis of the ability of the models to explain variability in returns, as defined by the rms error and mean-absolute error, the mean adjusted returns model with its assumption of constant expected returns is clearly the poorest.

The pairwise comparison of the models on the basis of Theil's coefficient again supports the finding that the factor approach is vastly superior to the others with respect to its ex-post forecasting ability. This is further confirmed in Table 4 which shows that the model has a low bias proportion, the lowest variance proportion and, consequently, the highest covariance proportion of all the models.

On the basis of these findings therefore, it is suggested that, for studies using Johannesburg Stock Exchange data, the two-factor model is the best benchmark to use in measuring security price performance. By using the two-factor approach considerable efficiencies are attained and the findings show that this approach is best for individual security abnormal return estimation for in excess of $75 \%$ of the cases. This is of particular relevance to research into the Johannesburg Stock Exchange where, because of the size of the market, small samples are usually used. Small sample size limits the advantages that can be attained through aggregation via the central limit theorem and small forecasting errors for individual securities are therefore important.

\section{References}

Brown, S.J. \& Warner, J.B. 1980. Measuring security price performance. J. Fin. Econ., No. 8.

Brown, S.J. \& Weinstein, M.I. 1985. Derived factors in event studies. J. Fin. Econ. No. 14.

Gilbertson, B. \& Goldberg, M. April, 1981. The market model and The Johannesburg Stock Exchange. Investment Anal. J., No. 17.

Page, M.J. 1986. Empirical testing of the Arbitrage Pricing Theory using data from the Johannesburg Stock Exchange. S. Afr. J. Bus. Mgmt., vol.17, no. 1.

Pindyck, R.S. \& Rubinfeld, D.L. 1981. Econometric Models and Economic Forecasts. 2nd. Ed.. McGraw-Hill International Book Company.

Ross, S.A. December 1976. The Arbitrage Theory of Capital Asset Pricing. J. Econ. Theory. No. 13. 